\title{
Case study in professionally-oriented training
}

\author{
Shamil M. Valitov ${ }^{1 a}$ \\ ${ }^{1}$ Kazan Federal University, 4, Butlerov st., Kazan, 420012, Russia
}

\begin{abstract}
Modern educational technologies are based on competence approach and focus on the future professional activity. Case study is one of the most significant technologies in modern higher education. The basic concepts used in the case study method are a "situation" and an "analysis", as well as their derivative - "analysis of the situation". The case study method of is one of the best tools for gaining experience, as it investigates practical situations that occur in managerial job. It combines theoretical knowledge with the analysis of the actual practical experience in accordance with a major. Doing case studies students read the description of the situation and offer divergent projects of managerial decisions that could be used by real managers dealing with the problem posed by the case study author. Answers to the questions posed in the case description are not given, as a rule, since the main purpose in the case analysis is to organize a discussion in the classroom or provoke speculations of those who do the self-study.
\end{abstract}

\section{Introduction}

A significant education quality increase is one of the priorities for the Russian Federation. In recent years, the universities of the country have been working on the introduction of new teaching methods. This is due to the emergence of new management disciplines, teaching of which requires new methods application. Modern educational technologies are built on a competent approach and focused on the future professional activity. A case study is among the most significant methods for modern higher education.

Case studies are designed to gain knowledge on subjects in which truth is pluralistic. Case study method could include the study of one or several cases [2].

The case study method in education dates back to the 1920s when it was first introduced at Harvard University in 1924. On average, case studies account for 30-40\% of study time in higher educational institutions of the USA. A student at Harvard University during his/her training analyzes 700 cases [4].

There are many definitions of the case (see Table 1), similar to each other to different extent.

\footnotetext{
${ }^{a}$ Corresponding author: SMValitov@kpfu.ru
} 
Table 1. Case Definitions

\begin{tabular}{|c|c|c|}
\hline Authors & Definition & Source \\
\hline John Boehrer & $\begin{array}{l}\text { This case tells about some events which throw the } \\
\text { participants into the dilemma of choosing between } \\
\text { several alternatives of possible behavior. Available } \\
\text { alternatives are evaluated differently by various } \\
\text { participants on the basis of their interests, values and } \\
\text { outlook. }\end{array}$ & $\begin{array}{l}\text { How to Teach a Case, } \\
\text { Harvard Press, } 1995\end{array}$ \\
\hline $\begin{array}{l}\text { Jose A. Gomez- } \\
\text { Ibanez }\end{array}$ & $\begin{array}{l}\text { This is a description of the real situation in which a } \\
\text { manager or an officer must make a decision. Moreover } \\
\text { the case can contain incomplete or conflicting } \\
\text { information about the situation, as well as different } \\
\text { assessments of the situation by participants. }\end{array}$ & $\begin{array}{l}\text { Learning by Case Method, } \\
\text { Harvard Press, } 1986 .\end{array}$ \\
\hline Williams Naumes & $\begin{array}{l}\text { This is a description of the real situation occurred in the } \\
\text { past, that detects a problem and a need for its } \\
\text { identification, analysis and solution. }\end{array}$ & $\begin{array}{l}\text { The Art and Graft of Case } \\
\text { Writing, Sage Publications, } \\
\text { 1999. }\end{array}$ \\
\hline
\end{tabular}

In our view a case is a description of the real current situation, which detects the problem and the need for its identification, analysis and solution at economic cost.

It would be naive to believe that it is possible to obtain some practical skills, especially when it comes to management in a classroom. With regard to this form of professional activity there is a perception that management is the art of making effective decisions in any situation, involving intuition as well, if by intuition we mean knowledge and real, observed or imaginary experience. It is this imaginary experience that we are trying to gain in the classroom. This type of experience is acquired in a particular situation. Analyzing it, we get an idea of what decision was made by a real manager in this situation, evaluate his decision, and then draw conclusions. The question is what decision could be made in a similar situation: the same or different? Assessments and conclusions are provided analyzing the issues that were not taken into account by the real manager.

The case study method is one of the best forms of gaining experience. However such traditional forms as discussions of key concepts and issues should not be neglected which are mostly employed in the humanities and business education.

\section{Method}

Case study is an investigation of practical situations that actually occur in managerial practice. This is a special method of teaching: the connection of theoretical knowledge obtained with the analysis of real practical experience according to the major. Myagkov considers that a distinctive feature of a case study is abandoning linear science development model; the challenge is to interpret the past event and not to place it in a single series with other events as possessing similar features, but to view it as unique, impossible to replicate under different conditions. There are American and European approaches to case studies. Table 2 presents a comparative analysis of these approaches.

Table 2. A comparative analysis of the American and European approaches to case studies

\begin{tabular}{|c|c|c|c|}
\hline \multirow{2}{*}{\multicolumn{2}{|c|}{ Indicators }} & \multicolumn{2}{|c|}{ Approaches to case -study } \\
\hline & & Harvard (USA) & Manchester (Great Britain) \\
\hline 1 & Case size & $20-25$ text pages & up to 13 text pages \\
\hline 2 & The only correct solution & Often presupposes & Multiple option \\
\hline 3 & Discussion & \multicolumn{2}{|c|}{ Discussion is encouraged } \\
\hline 4 & $\begin{array}{l}\text { Number of assignments } \\
\text { questions }\end{array}$ & \multicolumn{2}{|c|}{ Not given } \\
\hline
\end{tabular}


Classification of cases is as follows:

1. According to the size:

- Complete cases (20-25 p.) are designed for teamwork during several days;

- Short cases (3-5 p.) are designed for investigation in the classroom and involve a general discussion;

- Mini cases (1-2 p.) are designed for investigation in the classroom and are often used as illustrations of the theory.

2. According to the complexity:

- Cases for undergraduate students;

- Cases for graduate students;

- Cases for MBA programs.

Yin provides an enlarged research typology of case studies in the work «Case Study Research: Design and Methods», based on the number of units for analysis in one case and the amount of cases to be studied [8].

The work on the case in the classroom, as a rule, begins with an introduction of the teacher and the outline of the main issues. Students are divided into small groups of 4-5 people.

The main objectives of the students in doing case studies are as follows:

a) to read the description of the situation;

b) to offer divergent projects of managerial decisions that could be used by real managers dealing with the problem posed by the case study author.

Answers to the questions posed in the description of the case, are not given, as a rule, since the main purpose in the case analysis is to organize a discussion in the classroom or provoke speculations of those who do the self-study.

After thorough research of the material the groups present their solutions followed by a general discussion.

The class finishes with a summary of the students' performance provided by a teacher and small group's solutions analysis.

\section{Results}

In our view a successful case should meet the following criteria:

- meets the purpose of creation;

- meets a certain level of difficulty;

- is relevant and not to become obsolete very fast;

- illustrates both typical and atypical situations;

- develops critical thinking of students;

- encourages discussion in the classroom;

- has several possible solutions.

The author has been employing the case study method in his teaching practice since 2005. Mini-cases and short cases were applied for MBA students of Kazan State Finance and Economics Institute. In 2006, the complete case for MBA teamwork during the day was successfully applied.

Kazan Federal University Production Economy department, which is headed by the author, widely uses case study method for training undergraduate and graduate students [5 and 7]. A comparative analysis of selected cases collections is presented in Table 3. 
Table 3. Comparative analysis of the collections of cases

\begin{tabular}{lllc}
\hline & Indicators & & Case authors \\
\cline { 3 - 4 } & & Valitov S.M. & Meshcheryakova S.A. \\
\hline 1 & Number of pages & $8-12 \mathrm{pp}$. & $3-10 \mathrm{pp}$. \\
2 & Number of assignments/questions & $4-9$ & $2-5$ \\
3 & The only correct solution & & $\begin{array}{c}\text { Multiple option } \\
\text { Suggest discussion }\end{array}$ \\
\hline
\end{tabular}

\section{Conclusion}

What are the prospects of using a case study method?

Case study method is actively used in the educational process. In our opinion, the case study centers should be created in leading Russian universities, which will develop case studies on various subjects and train university teachers.

The next stage in the development of the case study method should include the development and use of virtual computer cases, which will familiarize students with the real sector of the economy.

\section{References}

1. Boehrer J, How to Teach a Case. Harvard Press, (1995)

2. Gerring J., Case Study Research: Principles and Practices. New York: Cambridge University Press. 265 p. (2007)

3. Gomez-Ibanez Jose A., Learning by Case Method. Harvard Press, (1986)

4. Kupryashin G.L., Avtonova A.S., et al., Situational analysis (case study) in training courses on public administration and politics: study guide. Moscow: New Textbook, 249 p. (2004)

5. Meshcheryakova S.A., Project Management: guidance paper. Kazan: KSFEI. (2010)

6. Naumes W., The Art and Graft of Case Writing. Sage Publications, (1999)

7. Valitov S.M., Case collection: «Competitive market strategies». Kazan: KSFEI. (2008)

8. Yin R., Case Study Research: Design and Methods. London, Thousand Oaks, New Delhi: Sage. 219 p. (2009) 